\title{
The effects of lycopene on methotrexate-induced liver injury in rats
}

\author{
Yucel $\mathrm{Y}^{1}$, Oguz E $\mathrm{E}^{2}$, Kocarslan $\mathrm{S}^{3}$, Tatli $\mathrm{F}^{1}$, Gozeneli $\mathrm{O}^{1}$, Seker $\mathrm{A}^{1}$, Sezen $\mathrm{H}^{4}$, Buyukaslan $\mathrm{H}^{5}$, \\ Aktumen $\mathrm{A}^{6}$, Ozgonul $\mathrm{A}^{1}$, Uzunkoy $\mathrm{A}^{1}$, Aksoy $\mathrm{N}^{4}$ \\ Harran University, Medical Faculty, Department of General Surgery, Sanliurfa, Turkey. \\ dryusufyucel@yahoo.com
}

\begin{abstract}
BACKGROUND: The aim of this study was to investigate the effects of lycopene (Lyc) on methotrexate (Mtx) induced liver toxicity in rats.

METHODS: Twenty-eight male Sprague-Dawley rats were divided into four equal groups: control, Lyc, Mtx and Mtx-L: Control group: Rats were given only the vehicle. Lyc group: Rats were given Lyc $(10 \mathrm{mg} / \mathrm{kg})$ with corn oil by oral gavage for ten days. Mtx group: Rats were injected intraperitoneally with a single dose of $20 \mathrm{mg} / \mathrm{kg}$ of Mtx and given corn oil by oral gavage. Mtx-L group: Rats were post-treated with $L y c(10 \mathrm{mg} / \mathrm{kg})$ for ten days after a single dose of Mtx $(20 \mathrm{mg} / \mathrm{kg})$. RESULTS: Mtx administration increased histopathological damage, TNF- $\alpha$, IL-1 $1 \beta$, TOS, TAS and OSI levels in tissues; AST, ALT levels in the blood. Sinusoidal dilatation, inflammatory cell infiltration and congestion were significantly improved in the Mtx-L aon histopathologic examination of the rats.

In Mtx-L group that were treated at the Lyc, TNF- $\alpha$ and IL-1 $\beta$ levels of liver tissue were decreased significantly compared to Mtx group whereas the decrease in OSI was not significant. Lyc treatment improved the AST and ALT values in Mtx-L group. But only AST improvement was significant.

CONCLUSIONS: The results of this study revealed that Lyc might be useful in protecting the liver from injury due to Mtx in rats by reducing the increased proinflammatory cytokine levels (Tab. 4, Fig. 1, Ref. 44). Text in PDF www.elis.sk. KEY WORDS: lycopene, liver injury, methotrexate, TNF- $\alpha$, IL-1 $\beta$, oxidative stresss.
\end{abstract}

\section{Introduction}

Methotrexate (Mtx) is an anti-neoplastic and immunosuppressive agent widely used in the treatment of various malignancies and autoimmune diseases $(1,2)$. It is toxic not only to cancer cells but also to normal cells. Its cytotoxic characteristic causes some life-threatening adverse effects. One of the most serious side effect is hepatotoxicity, limiting the use of this agent (1-5). The mechanism of Mtx-induced hepatotoxicity has not been fully understood yet $(6,7)$. However, some mechanisms that could explain the toxicity have been suggested. The mechanism of its action in creating damage can be ascribed to the production of free radicals and proinflammatory cytokines in consequence of using Mtx (8-10). Mtx administration induces oxidative stress

${ }^{1}$ Medical Faculty Department of General Surgery, Harran University, Sanliurfa, Turkey, ${ }^{2}$ Medical Faculty Department of Medical Pharmacology, Harran University, Sanliurfa, Turkey, ${ }^{3}$ Medical Faculty Department of Pathology, Harran University, Sanliurfa, Turkey, ${ }^{4}$ Medical Faculty Clinical Biochemistry and Faculty of Medicine, Harran University, Sanliurfa, Turkey, ${ }^{5}$ Medical Faculty Emergency Department, Harran University, and ${ }^{6}$ Medical Faculty Department of Pathology, Karabuk University, Karabuk, Turkey.

Address for correspondence: Y. Yucel, Dr, Harran University, Medical Faculty, Department of General Surgery, 63300, Sanliurfa, Turkey. Phone: +90.414.3183140, Fax: +90.414.3151181

Acknowledgements: This study was supported by a grant from Scientific Research Committee of Harran University (Grand number: 14111). and significantly reduces anti-oxidant enzymes such as superoxide dismutase in the liver and intestinal mucosa tissues of rats. Therefore, several anti-oxidant agents have been used to reduce its side effects (10). Akbulut et al. demonstrated the cytoprotective effects of amifostine, ascorbic acid and $\mathrm{N}$-acetylcysteine against Mtx-induced hepatotoxicity in rats (4). In addition, it has been reported that proinflammatory cytokines are involved in the pathogenesis of Mtx-induced nephrotoxicity and pneumonitis, suggesting that inflammation may also have a possible role in Mtx-induced hepatotoxicity (11-16).

Lycopene (Lyc) is a carotenoid pigment involved in vegetables and fruits, especially in tomato. It is a powerful anti-oxidant, anticancer and anti-inflammatory agent among all dietary carotenoids (17-20). Anti-oxidant and anti-inflammatory properties of Lyc are thought to be primarily responsible for its beneficial effects (21, $22)$. The fruits and vegetables including lycopene, have a very long history of use in the diet of humans without any safety problems. Additionally, the studies investigating the safety of lycopene support this. The deposition of lycopene in plasma, liver, and other tissues had no adverse effects and no teratogenic effects were observed in rat studies (23-27).

Several anti-oxidant agents have been showed to be effective experimentally by reducing the increased oxidative stress and proinflammatory cytokine levels in liver injury caused by Mtx. However, no study has been performed to evaluate effects of Lyc on hepatic injury by Mtx in rats yet. Therefore, this study 
was carried out to investigate the effects of Lyc on Mtx-induced hepatotoxicity in rats.

\section{Material and methods}

\section{Chemicals}

Mtx was purchased from a local pharmacy (Koçak ${ }^{\mathrm{TM}}$ Farma, Turkey). Lyc (Redivivo Lyc 10 \%; CWS/-TG, Basel, Switzerland) is provided by DSM Nutritional Products, Istanbul, Turkey. TNF- $\alpha$, IL-1 $\beta$ Elisa-kits and oxidative stress kits used for biochemical analysis were obtained from RayBio ${ }^{\circledR}$, Diaclona ${ }^{\circledR}$ and Rel Assay ${ }^{\circledR}$, respectively.

\section{Animals}

Twenty-eight healthy adult male Sprague-Dawley rats (weighing between 200-275 g) were used in this study. The animals were obtained from Dollvet Animal Laboratory (Sanliurfa, Turkey) where the experimental protocol was performed. The animals were allowed to acclimate under standard laboratory conditions (12-h light/12-h dark) in a room with controlled temperature (24 $\left.\pm 3{ }^{\circ} \mathrm{C}\right) 1$ week prior to the experimental study. The animals had free access to water and were fed a standard commercial pellet diet ad libitum. Dollvet Animal Care and Use Committee has approved the study (approval number: 2014/33). All experimental procedures were conducted in accordance with the Guide to the Care and Use of Laboratory Animals.

\section{Experimental protocol}

After seven days of acclimatization, rats were divided into four groups. Each group consists of seven rats according to the following protocol (Table 1):

Control group; Vehicle was administrated to the rats in this group and served as control.

Lyc group; Rats were given Lyc $(10 \mathrm{mg} / \mathrm{kg})$ with corn oil by oral gavage for ten days.

Mtx group; Rats were injected intraperitoneally (i.p.) with a single dose of of Mtx $(20 \mathrm{mg} / \mathrm{kg})(14,28)$ and given corn oil by oral gavage.

$M t x-L$ group; Rats were post-treated with Lyc $(10 \mathrm{mg} / \mathrm{kg})$ for ten days after a single dose of Mtx $(20 \mathrm{mg} / \mathrm{kg})$.
All rats were sacrificed by terminal anesthesia (ketamine 75 $\mathrm{mg} / \mathrm{kg}$ (i.p.), xylazine $8 \mathrm{mg} / \mathrm{kg}$ (i.p.)) and blood samples were collected at the end of the experiment. Serum samples were separated by centrifugation at $2000 \mathrm{x}$ g for 10 minutes at $25^{\circ} \mathrm{C}$. Livers were removed immediately and divided into two equivalent sections. One of the sections was fixed with $10 \%$ buffered formalin solution at room temperature for histopathological evaluation and the other one was stored at $-80{ }^{\circ} \mathrm{C}$ for biochemical analysis.

\section{Histopathological examination}

Liver tissues removed aseptically from all the groups were cut into small pieces and samples were fixed in $10 \%$ formaldehyde solution. The tissue sections $(5 \mu \mathrm{m})$ were mounted on glass slides and stained with hematoxylin-eosin (HE) for evaluating the liver structure. Five pieces of pathological sections were prepared from each rat. Each stained section was semi-quantitatively evaluated under light microscope (Olympus BX51 microscope with a magnification of $\mathrm{x} 200$ ) by a histologist blinded to the treatment group. Previously the scoring system by Akbulut et al. was used to assess the severity of hepatic injury: 1) sinusoidal dilatation; 2) inflammatory cell infiltration; 3 ) congestion, and 4) hydropic degeneration (cytoplasmic vacuolization/swelling of hepatocyte), with features scored as 0 (normal), 1 (mild), 2 (moderate), and 3 (severe). The maximum score of 12 indicated the most severe hepatic injury (4).

\section{Biochemical analysis \\ Tissue preparation and homogenization}

Before biochemical assays, hepatic tissues were weighed, broken down into very small pieces, and placed in empty glass tubes. $1 \mathrm{ml}$ of $140 \mathrm{mMKCl}$ solution per gram of tissue was added to each tube, and then all tissues were homogenized in a motordriven homogenizer. The homogenate was centrifuged at $2,800 \times \mathrm{g}$ for 10 min at $4{ }^{\circ} \mathrm{C}(29)$. The resulting supernatant was used for the levels of TAC, TOS, TNF- $\alpha$ and IL- $1 \beta$.

Alanine aminotransferase (ALT), aspartate aminotransferase (AST)) determination:

Plasma was used to measure AST and ALT as indicative parameters of hepatic function. The plasma activities of AST and

Tab. 1. Experimental study protocol.

\begin{tabular}{|c|c|c|c|c|c|c|c|c|c|c|c|}
\hline Groups & $1 *$ & $2 *$ & $3 *$ & $4 *$ & $5 *$ & 6* & $7 *$ & $8 *$ & 9* & $10^{*}$ & $11 *$ \\
\hline Control & $a, b$ & $b$ & b & $\mathrm{b}$ & $\mathrm{b}$ & b & $b$ & b & b & b & $\mathrm{e}$ \\
\hline Lyc & $\mathrm{b}, \mathrm{c}$ & $\mathrm{b}, \mathrm{c}$ & $\mathrm{b}, \mathrm{c}$ & $\mathrm{b}, \mathrm{c}$ & $\mathrm{b}, \mathrm{c}$ & $\mathrm{b}, \mathrm{c}$ & $\mathrm{b}, \mathrm{c}$ & $\mathrm{b}, \mathrm{c}$ & $\mathrm{b}, \mathrm{c}$ & $\mathrm{b}, \mathrm{c}$ & e \\
\hline Mtx & $\mathrm{d}$ & & & & & & & & & & e \\
\hline Mtx-L & $\mathrm{b}, \mathrm{c}, \mathrm{d}$ & $\mathrm{b}, \mathrm{c}$ & $\mathrm{b}, \mathrm{c}$ & $\mathrm{b}, \mathrm{c}$ & b,c & $\mathrm{b}, \mathrm{c}$ & $\mathrm{b}, \mathrm{c}$ & $\mathrm{b}, \mathrm{c}$ & $\mathrm{b}, \mathrm{c}$ & $\mathrm{b}, \mathrm{c}$ & $\mathrm{e}$ \\
\hline
\end{tabular}

*:Days, a:0.9\% NaCl( i.p.),b:Corn Oil (o.g.), c:Lycopene (10 mg/kg)(o.g.), d:Mtx (20 mg/kg) (i.p.), e:Euthanized

Tab. 2. Histopathologic examination results in rat liver tissues.

\begin{tabular}{|c|c|c|c|c|}
\hline \multirow{2}{*}{ Histopatalogic parameters } & \multicolumn{4}{|c|}{ Groups } \\
\hline & Control $^{\mathrm{x}}$ & $\operatorname{Lyc}^{x}$ & $\mathrm{Mtx}^{\mathrm{x}}$ & Mtx- $\mathrm{L}^{\mathrm{x}}$ \\
\hline Sinusoidal dilatation & $1.00(0.0-1.0)$ & $0.00(0.0-0.0)$ & $2.00(1.0-3.0)^{\mathrm{a}}$ & $0.00(0.0-1.0)^{\mathrm{b}}$ \\
\hline İnflammatory cell infiltration & $0.00(0.0-0.0)$ & $0.00(0.0-0.0)$ & $1.00(0.0-1.0)^{\mathrm{a}}$ & $0.00(0.0-1.0)^{\mathrm{b}}$ \\
\hline Congestion & $0.00(0.0-1.0)$ & $0.00(0.0-1.0)$ & $1.00(0.0-2.0)^{\mathrm{a}}$ & $0.00(0.0-1.0)^{\mathrm{b}}$ \\
\hline Hydropic degeneration & $0.00(0.0-1.0)$ & $0.00(0.0-1.0)$ & $1.00(0.0-3.0)^{\mathrm{a}}$ & $1.00(0.0-1.0)$ \\
\hline
\end{tabular}

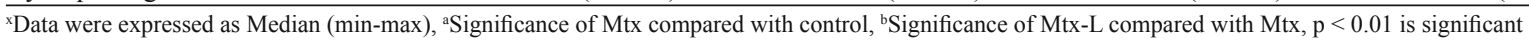


Tab. 3. Biochemical assessment results in rat liver tissues.

\begin{tabular}{lcccc}
\hline & \multicolumn{3}{c}{ Groups } & \multicolumn{2}{c}{} \\
\cline { 2 - 5 } & $\begin{array}{c}\text { Control }^{\mathrm{x}} \\
(\mathrm{n}=7)\end{array}$ & $\begin{array}{c}\text { Lyc }^{\mathrm{x}} \\
(\mathrm{n}=7)\end{array}$ & $\begin{array}{c}\text { Mtx }^{\mathrm{x}} \\
(\mathrm{n}=7)\end{array}$ & $\begin{array}{c}\text { Mtx-L }^{\mathrm{x}} \\
(\mathrm{n}=7)\end{array}$ \\
\hline TNF- $\alpha(\mathrm{pg} / \mathrm{g}$ protein) & $1820 \pm 102$ & $1607 \pm 35.9$ & $2412 \pm 175^{\mathrm{a}}$ & $1682 \pm 152^{\mathrm{b}}$ \\
IL-1 $\beta$ (pg/g protein) & $31.58 \pm 5.59$ & $37.73 \pm 5.87$ & $50.88 \pm 7.12^{\mathrm{a}}$ & $35.93 \pm 4.27^{\mathrm{b}}$ \\
TAC (mmol TroloxEq/g protein) & $0.29 \pm 0.02$ & $0.29 \pm 0.04$ & $0.37 \pm 0.04^{\mathrm{a}}$ & $0.30 \pm 0.04^{\mathrm{b}}$ \\
TOS $\left(\mu\right.$ mol $\mathrm{H}_{2} \mathrm{O}_{2}$ Eq/g protein) & $14.69 \pm 0.94$ & $13.86 \pm 1.77$ & $15.09 \pm 2.18$ & $14.83 \pm 2.03$ \\
OSI(ArbitraryUnits) & $5.08 \pm 0.52$ & $5.76 \pm 1.11$ & $6.06 \pm 0.74^{\mathrm{a}}$ & $4.92 \pm 1.12$ \\
\hline
\end{tabular}

TNF- $\alpha$ : Tumor Necrosis Factor-alpha, IL-1ß: Interleukin-1 beta, TAC (nmolTroloxEqv./mg protein): Total antioxidant capacity, TOS (nmol $\mathrm{H}_{2} \mathrm{O}_{2}$ Eqv./mg protein): Total oxidative status, OSI (Arbitrary Unite): Oxidative stress index, ${ }^{\mathrm{D}}$ Data represent as Mean $\pm \mathrm{SD}$, aSignificance of Mtx compared with control, ${ }^{\mathrm{b}}$ Significance of Mtx-L compared with Mtx, $\mathrm{p}<0.01$ is significant

ALT were measured by commercially available kits using an autoanalyser (Abbott c16000 ${ }^{\circledR}$ Abbott Laboratories)

\section{Determination of oxidative stress biomarkers \\ Measurement of TOS and TAC levels}

TOS and TAC levels were calculated by Erel's methods, which are automated and colorimetric (30-32). The percentage of TOS level to TAC level was regarded as oxidative stress index (OSI) $(33,34)$. The unit of hepatic tissue TOS and TAC was $\mu$ mole $\mathrm{H}_{2} \mathrm{O}_{2}$ Equiv./gram protein and millimole TroloxEquiv./gram protein, respectively (34). The hepatic tissue OSI value was calculated as follows: OSI $=\left[\left(\mathrm{TOS}, \mu\right.\right.$ mole $\mathrm{H}_{2} \mathrm{O}_{2}$ Equiv./gram protein $) /(\mathrm{TAC}$, millimole Trolox Equiv./gram protein $) \times 100$ ]. The results were expressed as arbitrary units (AU) (35).

\section{Determination of proinflammatory cytokines}

TNF- $\alpha\left(\right.$ RayBio $\left.^{\circledR}\right)$ and IL-1 $\beta$ (Diaclone trademark) levels were measured using ELISA kits according to the manufacturer's instructions. TNF- $\alpha$ and IL- $1 \beta$ levels are expressed $\mathrm{pg} / \mathrm{g}$ protein. Statistical analysis

All data are expressed as mean \pm standard deviation (SD). The Kruskal-Wallis analysis of variance method, followed by the application of the non-parametric Mann-Whitney U-test, with Bonferroni correction for binary comparisons to evaluate differences between the experimental groups. Probability values (P) less than 0.05 were considered statistically significant. All data were processed using the SPSS 16.0 for Windows statistical software package (SPSS Inc., Chicago, IL).

\section{Results}

\section{Histopathological results}

In group of Mtx, tissue damage was revealed in all histopathological parameters (sinusoidal dilatation, inflammatory cell infiltration, congestion and hydropic degeneration) in liver tissue (Fig.1 IIa, b, c, d).

Liver tissue damage of rats in this group, compared with the liver tissue of those in the control group was statistically significant in all histopathological parameters.

Lyc group compared with control group was not statistically significant in all histopathological parameters (Tab. 1).

The severest tissue damage was in Mtx group, minimal tissue damage was in Lyc group (Tab. 2).

Sinusoidal dilatation, inflammatory cell infiltration and con- gestion improved significantly in the Mtx-L group compared with Mtx (Fig.1 III, Tab. 2).

\section{Biochemical results}

All the biochemical parameters of liver tissue samples except TOS was increased significantly in Mtx group compared with the control group (Tab. 3).

Lyc group compared with control group was not statistically significant in all the biochemical parameters (Tab. 3).

Mtx-L group was Lyc treatment group and Lyc, in this group, provided a significant reduction in proinflammatory cytokines (Tab. 3).

Biochemical results of tissue samples were statistically significant in compared with the treatment results of Mtx-L group (Tab. 3).

In the Mtx group, AST and ALT levels were increased significantly compared with the control group. The treatment that was applied in Mtx-L group reduced AST and ALT values. However, in the ML group, the treatment provided a significant improvement only in AST levels (Tab. 4).

\section{Discussion}

The results of this experimental study showed that Lyc reduced the pathological damage, oxidative stress and proinflammatory cytokine levels in rat liver tissues as well as AST and ALT levels in blood serum of rats.

Sinusoidal dilation, inflammatory cell infiltration and congestion improvement was observed significantly in Mtx-L group on histopathologic examination of the rats. In Mtx-L group treated with Lyc, TNF- $\alpha$ and IL-1 $\beta$ levels in liver tissue were decreased significantly compared to Mtx group whereas the decrease in OSI was not significant. Lyc treatment improved the AST and ALT values in Mtx-L group but only the decrease of AST was significant.

Tab. 4. Biochemical assessment results in serum.

\begin{tabular}{lcccc}
\hline & \multicolumn{4}{c}{ Groups } \\
\cline { 2 - 5 } & Control $^{\mathrm{x}}$ & Lyc $^{\mathrm{x}}$ & $\mathrm{Mtx}^{\mathrm{x}}$ & Mtx-L $^{\mathrm{x}}$ \\
\hline AST & $64.40 \pm 7.92$ & $89.40 \pm 30.04$ & $162.80 \pm 42.72^{\mathrm{a}}$ & $134.40 \pm 47.70^{\mathrm{b}}$ \\
ALT & $39.20 \pm 6.31$ & $43.60 \pm 15.37$ & $48.40 \pm 8.64^{\mathrm{a}}$ & $34.20 \pm 4.38$ \\
\hline
\end{tabular}

Hepatic serum aspartatetransaminase (AST), alaninetransaminase (ALT), ${ }^{\mathrm{D}}$ Data rep-

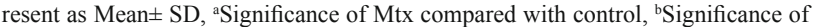
Mtx-L compared with Mtx, $\mathrm{p}<0.01$ is significant 


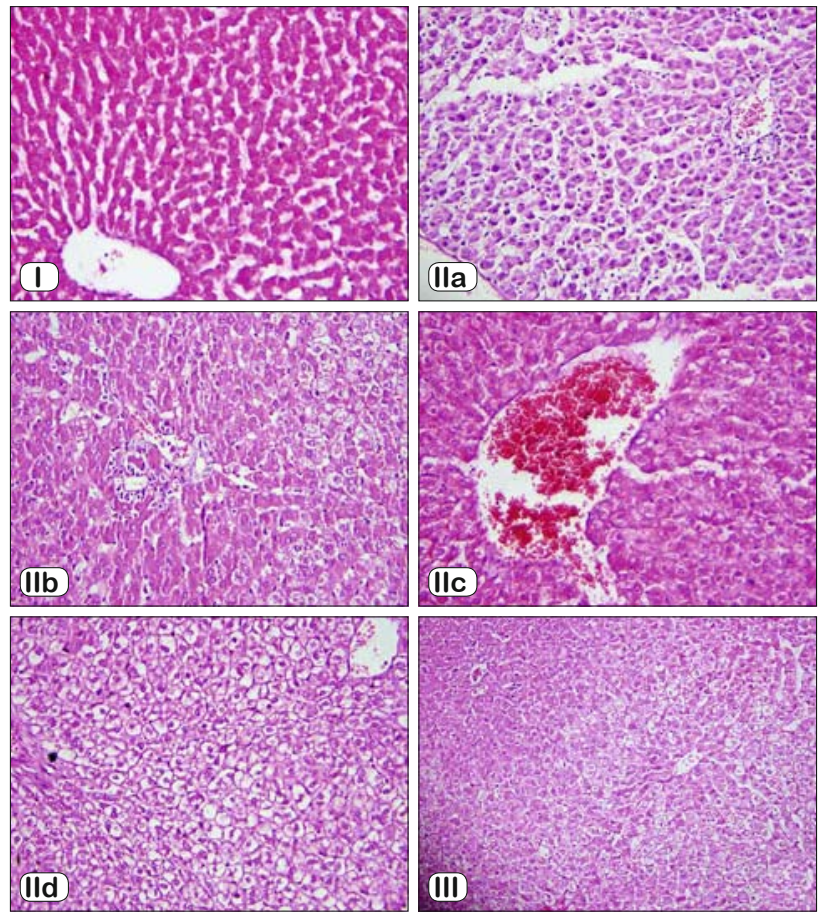

Fig. 1. I: Normal histological appearance of HE-stained control liver tissues. II: Histopathological effects of high-dose methotrexate on liver structure. a) sinusoidal dilatation, b) inflammatory cell infiltration, c) congestion, d) hydropic degeneration. III: The section is showing a significant improvement at sinusoidal dilatation, inflammatory cell infiltration and congestion in the liver tissue of rats in Mtx-L group.

Low dose long-term use and high dose short-term use of Mtx causes the elevation in hepatic serum transaminase levels. More disquieting is its association with changes in liver histopathology, especially with fibrosis and cirrhosis. These indicate liver cellular injury. We measured liver transaminase levels in serum and oxidative stress and pro-inflammatory cytokine levels in liver tissue to determine the hepatotoxicity due to MTx administration. There are several studies indicating that increased oxidative stress and proinflammatory cytokine levels may be effective in the Mtxinduced hepatotoxicity $(15,36,37)$.

The pathological examination of the liver of rats in the Mtx group, tissue damage was the highest in comparison to the other groups. The tissue OSI, TNF- $\alpha$ and IL- $1 \beta$ levels and serum AST and ALT levels were significantly higher in this group. The elevation of these parameters suggests that both oxidative stress and increase in proinflammatory cytokines may be involved in the hepatotoxicity caused by Mtx.

Mtx-L were the treatment group in our study. The microscopic examination showed that sinusoidal dilatation, inflammatory cell infiltration and congestion were significantly improved in the MtxL group. These findings suggest that Lyc might be effective in the treatment of Mtx-induced hepatotoxicity.

Anti-oxidants have a reducing effect on DNA, protein, lipid and cell membrane damage caused by oxidative stress. Therefore, melatonin, amifostine, ascorbic acid, $\mathrm{N}$-acetylcysteine and resveratrol as antioxidants have been used in hepatotoxicity caused by
Mtx and beneficial effects have been identified. These effects were realized by reducing the oxidative stress.

Lyc, a powerful anti-oxidant, has been showed to be effective in reducing the nephrotoxicity caused by cisplatin, via decreasing oxidative stress $(4,38-40)$. Lyc's also has anti-inflammatory and anti-cancer properties. The studies showed that it may be effective in reducing organ toxicity such as pancreas, testis and kidney $(39,41-$ 43). In this study, we investigated the effects of Lyc on MTX-induced hepatotoxicity. OSI parameters of the liver tissue of the rats were reduced by lyc treatment, but it was not significant. This result make us think that lycopen is not effective in preventing oxidative stress in the Mtx hepatotoxicity at a dose of $10 \mathrm{mg} / \mathrm{kg}$, used in this study.

Cytokines are polypeptide structure molecules secreting against microorganisms and other antigens to regulate immune and inflammatory responses. TNF- $\alpha$ and IL- $1 \beta$ play an active role in the inflammation. TNF- $\alpha$ is produced mainly by activated macrophages. A cytokine involved in systemic inflammation, mediates acute inflammation. Mtx causes an increase in TNF- $\alpha 40$. There are many studies showing that Lyc treatment reduces the increase in TNF- $\alpha$, one of the proinflammatory cytokines $(15,36$, $37,44)$. However, to the best of our knowledge there is not any study showing the effect of Lyc on IL-1 $\beta$ levels in liver injury caused by Mtx in rats. This study is the first study demonstrating that Lyc may be effective in reducing IL- $1 \beta$ Levels. In our study, both TNF- $\alpha$ and IL-1 $\beta$ levels were decreased significantly in MtxL group compared to Mtx-administrated group.

\section{Conclusion}

These results suggest that Lyc may be effective in reducing hepatotoxicity induced by Mtx via decreasing the levels of proinflammatory cytokines, but not OSI, at a dose of $10 \mathrm{mg} / \mathrm{kg}$, used in this study. We think that new studies with different doses of Lyc should be made to reveal the role of Lyc in Mtx-induced hepatotoxicity.

\section{References}

1. LoVecchio F, Katz KD, Watts DJ, Wood IO. Four-year experience with methotrexate exposures. J Med Toxicol 2008; 4 (3): 149-150.

2. Kose E, Sapmaz HI, Sarihan E, Vardi N, Turkoz Y, Ekinci N. Beneficial effects of montelukast against methotrexate-induced liver toxicity: a biochemical and histological study. Sci World J 2012.

3. Ghaffari AR, Noshad H, Ostadi A, Ghojazadeh M, Asadi P. The effects of milk thistle on hepatic fibrosis due to methotrexate in rat. Hepatitis Month 2011; 11 (6): 464.

4. Akbulut S, Elbe H, Eris C, Dogan Z, Toprak G, Otan E, Turkoz Y. (2014). Cytoprotective effects of amifostine, ascorbic acid and N-acetylcysteine against methotrexate-induced hepatotoxicity in rats. World J Gastroenterol 2014; 20 (29): 10158.

5. Cronstein BN. Molecular mechanism of methotrexate action in inflammation. Inflammation 1992; 16 (5): 411-423.

6. Bath RK, Brar NK, Forouhar FA, Wu GY. A review of methotrexateassociated hepatotoxicity. J Digest Dis 2014; 15 (10): 517-524.

7. Pandit A, Sachdeva T, Bafna P. Drug-Induced Hepatotoxicity: A Review. JAPS 2012; 2: 233-243. 
8. Olsen NJ, Spurlock CF, Aune TM. Methotrexate induces production of IL-1 and IL-6 in the monocytic cell line U937. Arthritis Res Ther 2014; 16: $17-25$.

9. Tamilselvi E, Haripriya D, Hemamalini M, Pushpa G, Swapna S. Association of Disease Severity with IL-1 levels in Methotrexate-treated Psoriasis Patients. Scand J Immunol 2013; 78 (6): 545-553.

10. Coleshowers CL, Oguntibeju OO, Ukpong M, Truter EJ. Effects of methotrexate on antioxidant enzyme status in a rodent model: peer reviewed original article. Med Technol SA, 2010; 24 (1): 4-9.

11. Kim YJ, Song M, Ryu JC. Inflammation in methotrexate-induced pulmonary toxicity occurs via the p38 MAPK pathway. Toxicol 2009; 256 (3): 183-190.

12. Logan RM, Stringer AM, Bowen JM, Yeoh ASJ, Gibson RJ, Sonis ST, Keefe DM. The role of pro-inflammatory cytokines in cancer treatmentinduced alimentary tract mucositis: pathobiology, animal models and cytotoxic drugs. Cancer Ttreat Rev 2007; 33 (5): 448-460.

13. Hamada K, Kakigawa N, Sekine S, Shitara Y, Horie T. Disruption of ZO-1/claudin-4 interaction in relation to inflammatory responses in methotrexate-induced intestinal mucositis. Cancer Chemother Pharmacol 2013; 72 (4): 757-765.

14. Asvadi I, Hajipour B, Asvadi A, AsI NA, Roshangar L, Khodadadi A. Protective effect of pentoxyfilline in renal toxicity after methotrexate administration. Eur Rev Med Pharmacol Sci 2011; 15 (9): 1003-1009.

15. Pierine DT, Navarro MEL, Minatel IO, Luvizotto RAM, Nascimento AF, Ferreira ALA, Corrêa CR. Lycopene supplementation reduces TNF- $\alpha$ via RAGE in the kidney of obese rats. Nutrition Diabet 2014; 4 (11): e142.

16. Kirbas A, Cure MC, Kalkan Y, Cure E, Tumkaya L, Sahin OZ, Pergel A. Effect of infliximab on renal injury due to methotrexate in rat. Iran J Kidney Dis 2015; 9 (3): 221-229.

17. Bayramoglu G, Bayramoglu A, Altuner Y, Uyanoglu M, Colak S. The effects of lycopene on hepatic ischemia/reperfusion injury in rats. Cytotechnol 2015; 67 (3): 487-491.

18. Kim H. Inhibitory mechanism of Lycopene on cytokine expression in experimental pancreatitis. Ann N Y Acad Sci 2011; 1229 (1): 99-102.

19. Darwish SF, El-Bakly WM, Arafa HM, El-Demerdash E. Targeting TNF- $\alpha$ and NF- $\kappa$ B Activation by Bee Venom: Role in Suppressing Adjuvant Induced Arthritis and Methotrexate Hepatotoxicity in Rats. PLoS One 2013: e79284.

20. Yonar ME. Protective effect of lycopene on oxidative stress and antioxidant status in Cyprinus carpio during cypermethrin exposure. Environm Toxicol 2013; 28 (11): 609-616.

21. Rao AV, Agarwal S. Role of lycopene as antioxidant carotenoid in the prevention of chronic diseases: a review. Nutrit Res 1999; 19 (2): 305-323.

22. Marcotorchino J, Romier B, Gouranton E, Riollet C, Gleize B, Malezet-Desmoulins C, Landrier JF. Lycopene attenuates LPS-induced TNF- $\alpha$ secretion in macrophages and inflammatory markers in adipocytes exposed to macrophage-conditioned media. Mol Nutrit Food Res 2012; 56 (5): 725-732.

23. Mellert W, Deckardt K, Gembardt C, Schulte S, Van Ravenzwaay B, Slesinski RS. Thirteen-week oral toxicity study of synthetic lycopene products in rats. Food Chem Toxicol 2002; 40 (11): 1581-1588.

24. Papaioannou EH, Kyriakides ML, Karabelas AJ. Natural Origin Lycopene and Its 'Green'Downstream Processing. Crit Rev Food Sci Nutrit 2015.

25. McClain RM, Bausch J. Summary of safety studies conducted with synthetic lycopene. Regul Toxicol Pharmacol 2003; 37 (2): 274-285.

26. Matulka R A, Hood AM, Griffiths JC. Safety evaluation of a natural tomato oleoresin extract derived from food-processing tomatoes. Regul Toxicol Pharmacol 2004; 39 (3): 390-402.
27. Jonker D, Kuper CF, Fraile N, Estrella A, Otero CR. Ninety-day oral toxicity study of lycopene from Blakeslea trispora in rats. Regul Toxicol Pharmacol 2003; 37 (3): 396-406.

28. Bozkurt M, Em S, Oktayoglu P, Turkcu G, Yuksel H, Sariyildiz MA, Kuyumcu M. Carvacrol prevents methotrexate-induced renal oxidative injury and renal damage in rats. Clin Invest Med 2014; 37 (1): 19-25.

29. Rabus M, Demirbağ R, Sezen Y, Konukoğlu O, Yildiz A, Ere O, Yakut C. Plasma and tissue oxidative stress index in patients with rheumatic and degenerative heart valve disease. Turk Kardiyol Dern Ars 2008; 36 (8): 536-540.

30. Cao G, Prior RL. Comparison of different analytical methods for assessing total antioxidant capacity of human serum. Clin Chem 1998; 44 (6): 1309-1315.

31. Erel O. A novel automated direct measurement method for total antioxidant capacity using a new generation, more stable ABTS radical cation. Clin Chem 2004; 37 (4): 277-285.

32. Erel O. A new automated colorimetric method for measuring total oxidant status. Clin Biochem 2005; 38 (12): 1103-1111.

33. Aycicek A, Erel O, Kocyigit A, Selek S, Demirkol MR. Breast milk provides better antioxidant power than does formula. Nutrition 2006; 22 (6): 616-619.

34. Harma M, Harma M, Erel O. Increased oxidative stress in patients with hydatidiform mole. Swiss Med Week 2003; 133 (41-42): 563-566.

35. Aycicek A, Erel O, Kocyigit A. Increased oxidative stress in infants exposed to passive smoking. Eur J Pediatr 2004; 164 (12): 775-778.

36. He Q, Zhou W, Xiong C, Tan G, Chen M. Lycopene attenuates inflammation and apoptosis in post-myocardial infarction remodeling by inhibiting the nuclear factor- $\kappa \mathrm{B}$ signaling pathway. Mol Med Rep 2015; 11 (1): 374-378.

37. Guo Y, Liu Y, Wang Y. Beneficial effect of lycopene on anti-diabetic nephropathy through diminishing inflammatory response and oxidative stress. Food Function 2015; 6 (4): 1150-1156.

38. Yonar ME. Protective effect of lycopene on oxidative stress and antioxidant status in Cyprinus carpio during cypermethrin exposure. Environ Toxicol 2013; 28 (11): 609-616.

39. Atessahin A, Yilmaz S, Karahan I, Ceribasi AO, Karaoglu A. Effects of lycopene against cisplatin-induced nephrotoxicity and oxidative stress in rats. Toxicol 2005; 212 (2): 116-123.

40. Tunali-Akbay T, Sehirli O, Ercan F, Sener G. Resveratrol protects against methotrexate-induced hepatic injury in rats. J Pharm Pharm Sci 2010; 13 (2): 303-310

41. Dogukan A, Tuzcu M, Agca CA, Gencoglu H, Sahin N, Onderci M, Sahin K. A tomato lycopene complex protects the kidney from cisplatininduced injury via affecting oxidative stress as well as Bax, Bcl-2, and HSPs expression. Nutr Cancer 2011; 63 (3): 427-434.

42. Boeira SP, Borges Filho C, Del'Fabbro L, Roman SS, Royes LFF, Fighera MR, Furian AF. Lycopene treatment prevents hematological, reproductive and histopathological damage induced by acute zearalenone administration in male Swiss mice. Exp Toxicol Pathol 2014; 66 (4): 179-185.

43. Shea B, Swinden MV, Tanjong Ghogomu E, Ortiz Z, Katchamart W, Rader T, Tugwell P. Folic acid and folinic acid for reducing side effects in patients receiving methotrexate for rheumatoid arthritis. Cochrane Database Syst Rev 2013; 5:CD000951.

44. Hazewindus M, Haenen GR, Weseler AR, Bast A. Protection against Chemotaxis in the Anti-Inflammatory Effect of Bioactives from Tomato Ketchup. PloS One 2014; 9 (12), e114387.

Received December 21, 2016. Accepted January 13, 2017. 